\title{
Implementation of supply chain management in supplier performance assessment using Analytical Hierarchy Process (AHP) Objective Matrix (OMAX) and Traffic Light System
}

\author{
Irwan Sukendar, Nurwidiana, Diah Nurul Hidayati \\ Industrial Engineering Department, Universitas Islam Sultan Agung, Kaligawe Street km 4 Semarang, Indonesia.
}

\begin{abstract}
This study focuses on researching the implementation of supply chain management in supplier performance measurement using Analytical Hierarchy Process (AHP) Objective Matrix (OMAX) and Traffic Light System. The method used consisted of several stages: Identification stage of criteria variable and subcriteria variable, designing hierarchy AHP structure, calculating the weight of each criterion and subcriteria, supplier performance appraisal using OMAX method, calculating the total value of each supplier perfomance and identifying the performance of each supplier Using color indicator from Traffic Light System. Based on the results of the research, it can be seen that 9 out of 10 suppliers that are considered have a good performance while 1 supplier has a performance under the target.
\end{abstract}

\section{Introduction}

A manufacturing company in Indonesia that produces AlQuran has a pretty good performance in product marketing. The company holds a market share of about $30 \%$ of all domestic Quran publishers. Even the company has been certified ISO 9001: 2008 in terms of quality management. As one of the companies that have been certified ISO 9001: 2008 then the performance evaluation of supplier activities are regularly implemented. Implementation of supplier performance evaluation is done based on several criteria such as quality, price, payment and delivery where each criteria already has the standard set by the company.

However, supplier performance evaluation is still fairly simple and has not used the weighting of the criteria. In addition, there is also one criterion that has two assessments to consider but the criteria are not broken down as subcriteria but are made into one. Assessment criteria need to be weighted because the importance of each criterion is different. Whereas if a criterion has more than one appraisal it is better if each assessment is separated into several subcriteria

Based on the above explanation it is seen that the evaluation of suppliers made has some shortcomings. The first deficiency is that there is no weighting on the criteria and subcriteria, it is not considered to separate criteria that have more than one assessment to be broken down into subcriteria, as well as identify the weaknesses and advantages of each qualitative supplier.

The problem is part of the supply chain theme. Much research on the subject has grown tremendously. Some of them serve as literature in this research

[1] analyze the supplier selection process, [2] conduct supplier evaluation with Vendor Performance Indicator and Analytical Hierarchy Process (AHP) method, meanwhile [3] designing the Supplier Rating and Selection System by Using AHP Method and Traffic Light System. [4] Write a measurement of supply chain performance by reviewing the literature. Meanwhile,[5] Write the Total Quality Management (TQM) measurement in the supply chain section with research objects of health institutions. [6] Writing the implementation of supply chain management on aviation manufacturing, [7] Researching the collaboration between supply chain networks, while [8] Writing about the optimal delivery time to minimize tardiness and shipping costs. [9] Write about drivers that affect supply chain complexity, while [10] Wrote a key success factor determination to implement reverse logistics using fuzzytopsis.

On the basis of these literatures, one of the structured methods that can be used to measure the criteria and subcriteria weighting based on the level of importance between the criteria and the level of importance between subcriteria is by using the Analytical Hierarchy Process (AHP).

Furthermore, to see how the overall performance of each supplier and also to know the advantages of the shortage of each supplier method that can be applied properly is the method of Objective Martix (OMAX) and Traffic Light System. This is because the OMAX method not only analyzes the overall supplier's performance but also analyzes the performance of each criterion.

On the basis of the problem solving hypothesis, this study aims to evaluate supplier performance in this study by using AHP, OMAX and Traffic Light System methods.

* Corresponding author: irwan@unissula.ac.id 


\section{Methods}

There are three methods used in this research. The first method is analytical hierarchy process (AHP), the second is Objective Matrix (OMAX) and the third is Traffic Light System.

Analytical hierarchy process (AHP) method will be used to find out how the relationship between criteria and subcriteria based on hierarchy structure and to know the importance of each criterion and subcriteria. The AHP method will be used to see what criteria and subcriteria will be used to perform performance evaluations and also to find out how much weight each of the criteria and subcriteria

Objective Matrix (OMAX) and Traffic Light System methods will be used to determine the performance of each supplier and also to know the advantages and disadvantages of each supplier.

The OMAX method is used to know the performance value of each supplier while the traffic light system is used as an indicator of the value of each performance value. If the performance value is at level 8-10 then the supplier's performance gets the green indicator color indicating that the supplier's performance is the same or exceed the target, if the performance value is at level 4-7 then the supplier's performance gets the yellow indicator color indicates that the performance has not been reached even though the value Is approaching the target. Whereas if the performance value is at the 0-3 level then the supplier's performance gets the red indicator color indicating that the performance is really below the set target and needs immediate improvement.

\section{Results}

\subsection{Identify criteria and subcriteria}

The first step of the research is to identify the criteria variable in supplier performance measurement. Based on the results of brainstorming with the company then it can be identified six criteria variables. The six criteria are: quality, price, delivery, payment, flexibility and responsiveness

The next step, each criterion identified subcriteria. Subcriteria can be identified: on Quality criteria, four sub criteria are identified. In the price criteria identified two subcriteria, on the delivery criteria identified two sub criteria, on the criteria of payer identified two sub criteria, on the criteria of flexibility identified two criteria and on the criteria of responsiveness identified four sub criteria. All six criteria and 16 criteria can be seen in Table 1 .

\subsection{Design of AHP Hierarchy Structure and weighting}

The criteria and subcriteria tables should be described in the Hierarchy AHP Structure form. In addition to the criteria and sub criteria, all suppliers totaling 10 are also included in the hierarchy structure.

Subsequently all criteria and sub criteria need to be weighted. This weight is derived from the judgments made by the most authoritative official in the company. In this case is the head of purchasing department. The assessment is normalized so that it becomes a weight.

Tabel 1. Criteria and Subcriteria

\begin{tabular}{|c|c|c|}
\hline No & Criteria & SubCriteria \\
\hline \multirow[t]{4}{*}{1} & \multirow[t]{4}{*}{ Quality } & Quality consistency (SK1) \\
\hline & & The existence of warranty (SK2) \\
\hline & & $\begin{array}{l}\text { Inclusion of product specification } \\
\text { sheet (SK3) }\end{array}$ \\
\hline & & $\begin{array}{l}\text { Consistency of packaging form } \\
\text { (SK4) }\end{array}$ \\
\hline \multirow[t]{2}{*}{2} & \multirow[t]{2}{*}{ Price } & Competitive product prices (SK5) \\
\hline & & Discounting (SK6) \\
\hline \multirow[t]{2}{*}{3} & \multirow[t]{2}{*}{ delivery } & Timeliness of delivery (SK7) \\
\hline & & $\begin{array}{l}\text { Accuracy of quantity of product } \\
\text { shipped (SK8) }\end{array}$ \\
\hline \multirow[t]{2}{*}{4} & \multirow{2}{*}{ payment } & Grace period of payment (SK9) \\
\hline & & Way of payment (SK10) \\
\hline \multirow[t]{2}{*}{5} & \multirow[t]{2}{*}{ Flexibility } & $\begin{array}{l}\text { Eligibility to meet delivery time } \\
\text { shift (SK11) }\end{array}$ \\
\hline & & $\begin{array}{l}\text { The ability to meet changes in the } \\
\text { number of products ordered } \\
\text { (SK12) }\end{array}$ \\
\hline \multirow[t]{4}{*}{6} & \multirow[t]{4}{*}{ Responsiveness } & $\begin{array}{l}\text { Speed confirmation of order } \\
\text { availability (13) }\end{array}$ \\
\hline & & $\begin{array}{l}\text { Speed responding to change of } \\
\text { delivery time (14) }\end{array}$ \\
\hline & & $\begin{array}{l}\text { Speed responds to changes in order } \\
\text { quantity (SK15) }\end{array}$ \\
\hline & & $\begin{array}{l}\text { Speed of responding to product } \\
\text { complaints (SK16) }\end{array}$ \\
\hline
\end{tabular}

\subsection{Performance Supplier Rating and Traffic Light System}

Performance appraisal of suppliers is done by OMAX method. Temporal Traffic Light System method is used to give the indicator color on the performance of the supplier. The performance value of each supplier and the indicator color of each supplier can be seen below:

Tabel 2. Performance and Traffic Light System

\begin{tabular}{|c|l|c|c|}
\hline No & \multicolumn{1}{|c|}{ Supplier } & $\begin{array}{c}\text { Performanc } \\
e\end{array}$ & Level \\
\hline 1 & CV.Multiwarna & 9.250 & 9 \\
\hline 2 & PT.Hana Grafika & 9.168 & 9 \\
\hline 3 & PT.Pura Barutama & 8.969 & 8 \\
\hline 4 & PT.Pabrik Kertas Noree & 8.969 & 8 \\
\hline 5 & CV.Dirgantara & 8.947 & 8 \\
\hline 6 & PT.Manggala Indo Nusa & 8.908 & 8 \\
\hline 7 & PT.Maritama & 8.674 & 8 \\
\hline 8 & CV. Berkat Lamandau & 8.531 & 8 \\
\hline 9 & PT.Hasta Yuga Halim & 8.531 & 8 \\
\hline 10 & $\begin{array}{l}\text { PT.Puri Nusa Eka } \\
\text { Persada }\end{array}$ & 7.474 & 7 \\
\hline
\end{tabular}

Based on the performance table, it shows that from 10 suppliers, two suppliers have excellent performance, seven suppliers have good performance, and one supplier has enough performance. 
Traffic Light System method shows that Nine suppliers are given green indicator color which means having good performance and very good. So it is recommended to be maintained. Meanwhile, one supplier is colored yellow indicator which means to have to improve its performance again.

\section{Conclusion}

There are 6 criteria and 16 subcriteria used to assess supplier performance. Based on the assessment of the 6 criteria and the 16 subcriteria, it can be concluded that the total performance score for 9 suppliers is at level 8 and also level 9 which means that the performance on the nine suppliers is equal or exceeds the target while there is one supplier that has total value Performance at level 7 which means under the performance of the supplier is under the target but sudha approaching, so it needs to be done follow-up in the form of two-way communication so that the performance on the supplier can be in accordance with the target

\section{References}

1 Verma, R., and Pullman, M.E.: 'An analysis of the supplier selection process', Omega, 1998, 26, (6), pp. 739-750

2 Andika, D., Anggraeni, S.K., and Sirajuddin, S.: 'Usulan Pemilihan Supplier Bahan Baku Tetap Menggunakan Vendor Performance Indicator dan Analytical Hierarchy Process (AHP)', Jurnal Teknik Industri Untirta, 2013, 1, (2)

3 Iriani, Y.: 'PERANCANGAN SISITEM PENILAIAN DAN SELEKSI SUPPLIER DENGAN MENGGUNAKAN METODE AHP DAN TRAFFICT LIGHT SYSTEM', 2009

4 Arzu Akyuz, G., and Erman Erkan, T.: 'Supply chain performance measurement: a literature review', International Journal of Production Research, 2010, 48, (17), pp. 5137-5155

5 Turkyilmaz, A., Bulak, M.E., and Zaim, S.: 'Assessment of TQM Practices as a Part of Supply Chain Management in Healthcare Institutions', International Journal of Supply Chain Management, 2015, 4, (4)

6 Axtman, S.J., and Wilck, J.: 'A Review of Aviation Manufacturing and Supply Chain Processes', International Journal of Supply Chain Management, 2015, 4, (4)

7 Kampstra, R., Ashayeri, J., and Gattorna, J.: 'Realities of supply chain collaboration', The International Journal of Logistics Management, 2006, 17, (3), pp. 312-330

8 Dumitrescu, S., Steiner, G., and Zhang, R.: 'Optimal delivery time quotation in supply chains to minimize tardiness and delivery costs', Journal of Scheduling, 2015, 18, (1), pp. 3-13
9 Serdarasan, S.: 'A review of supply chain complexity drivers', Computers \& Industrial Engineering, 2013, 66, (3), pp. 533-540

10 Agrawal, S., Singh, R.K., and Murtaza, Q.: 'Prioritizing critical success factors for reverse logistics implementation using fuzzy-TOPSIS methodology', Journal of Industrial Engineering International, 2016, 12, (1), pp. 15-27 